\title{
Impact of gas-to-particle partitioning approaches on the simulated radiative effects of biogenic secondary organic aerosol
}

\author{
C. E. Scott ${ }^{1}$, D. V. Spracklen ${ }^{1}$, J. R. Pierce ${ }^{2}$, I. Riipinen ${ }^{3}$, S. D. D’Andrea ${ }^{2}$, A. Rap ${ }^{1}$, K. S. Carslaw ${ }^{1}$, P. M. Forster ${ }^{1}$, \\ P. Artaxo ${ }^{4}$, M. Kulmala ${ }^{5}$, L. V. Rizzo ${ }^{6}$, E. Swietlicki ${ }^{7,8}$, G. W. Mann ${ }^{1,9}$, and K. J. Pringle ${ }^{1}$ \\ ${ }^{1}$ School of Earth and Environment, University of Leeds, Leeds, LS2 9JT, UK \\ ${ }^{2}$ Department of Atmospheric Science, Colorado State University, Ft. Collins, CO, USA \\ ${ }^{3}$ Department of Applied Environmental Science \& Bolin Centre for Climate Research, Stockholm University, \\ 10691 Stockholm, Sweden \\ ${ }^{4}$ Institute of Physics, University of São Paulo, São Paulo, Brazil \\ ${ }^{5}$ Department of Physics, University of Helsinki, P.O. Box 64, 00014 Helsinki, Finland \\ ${ }^{6}$ Department of Earth and Exact Sciences, Institute of Environmental, Chemical and Pharmaceutics Sciences, \\ Federal University of São Paulo, UNIFESP, Diadema, Brazil \\ ${ }^{7}$ Division of Nuclear Physics, Lund University, P.O. Box 118, 22100 Lund, Sweden \\ ${ }^{8}$ Centre for Environmental and Climate Research, Lund University, P.O. Box 118, 22100 Lund, Sweden \\ ${ }^{9}$ National Centre for Atmospheric Science, University of Leeds, Leeds, LS2 9JT, UK
}

Correspondence to: C. E. Scott (c.e.scott@leeds.ac.uk)

Received: 25 January 2015 - Published in Atmos. Chem. Phys. Discuss.: 17 February 2015

Revised: 14 October 2015 - Accepted: 19 October 2015 - Published: 24 November 2015

\begin{abstract}
The oxidation of biogenic volatile organic compounds (BVOCs) gives a range of products, from semivolatile to extremely low-volatility compounds. To treat the interaction of these secondary organic vapours with the particle phase, global aerosol microphysics models generally use either a thermodynamic partitioning approach (assuming instant equilibrium between semi-volatile oxidation products and the particle phase) or a kinetic approach (accounting for the size dependence of condensation). We show that model treatment of the partitioning of biogenic organic vapours into the particle phase, and consequent distribution of material across the size distribution, controls the magnitude of the first aerosol indirect effect (AIE) due to biogenic secondary organic aerosol (SOA). With a kinetic partitioning approach, SOA is distributed according to the existing condensation sink, enhancing the growth of the smallest particles, i.e. those in the nucleation mode. This process tends to increase cloud droplet number concentrations in the presence of biogenic SOA. By contrast, an approach that distributes SOA according to pre-existing organic mass restricts the growth of the smallest particles, limiting the number that are able to form cloud droplets. With an organically mediated new particle
\end{abstract}

formation mechanism, applying a mass-based rather than a kinetic approach to partitioning reduces our calculated global mean AIE due to biogenic SOA by $24 \%$. Our results suggest that the mechanisms driving organic partitioning need to be fully understood in order to accurately describe the climatic effects of SOA.

\section{Introduction}

Biogenic volatile organic compounds (BVOCs), such as monoterpenes and isoprene, are emitted into the atmosphere by vegetation (Guenther et al., 1995, 2006) and are rapidly oxidised. The oxidation of BVOCs yields products with lower volatility, which may partition to the particle phase forming secondary organic aerosol (SOA). Organic compounds contribute a large fraction of submicron aerosol mass (Murphy et al., 2006; Zhang et al., 2007; Jimenez et al., 2009) with important impacts on air quality and climate (Fiore et al., 2012; Scott et al., 2014).

The part of the aerosol size distribution to which SOA is added affects the number, size and composition of particles in 
the atmosphere; in particular, the number of particles that are able to act as cloud condensation nuclei (CCN). The availability of $\mathrm{CCN}$ controls cloud droplet number concentrations (CDNC) and subsequently cloud albedo; therefore, the manner in which organics are distributed has potential implications for the first aerosol indirect effect (AIE) of biogenic SOA.

The presence of SOA can affect atmospheric CCN concentrations in several ways. Firstly, the condensation of SOA may grow particles to larger sizes, increasing $\mathrm{CCN}$ concentrations (Riipinen et al., 2012). However, this enhanced growth increases the condensation sink for potential nucleating vapours and the coagulation sink for nucleation mode particles. The net change to $\mathrm{CCN}$ concentration therefore reflects the competition between particle growth and the scavenging of particles and vapours. Secondly, condensation of water-soluble organic species can make hydrophobic particles more hydrophilic, providing an additional source of new CCN (Petters et al., 2006).

The transfer of semi-volatile gas-phase organic species into the condensed phase is often treated assuming thermodynamic equilibrium (Pankow, 1994; Odum et al., 1996). When simulating the evolution of the aerosol size distribution, a consequence of assuming instant equilibrium is that the net condensation of new organic mass scales with the existing organic aerosol mass size distribution (Kroll and Seinfeld, 2008; Pierce et al., 2011; Riipinen et al., 2011). Because aerosol mass scales with diameter cubed, small particles that require condensational growth to reach climatically relevant sizes receive only a trivial fraction of the new SOA and subsequently do not grow.

However, if the volatility of organic oxidation products in the atmosphere is further reduced (i.e. through gas or particle-phase chemistry; Jimenez et al., 2009; Donahue et al., 2011; Ehn et al., 2014), they may condense kinetically according to the Fuchs-corrected surface area of existing particles and a larger proportion of the condensable mass will be added to the nucleation mode (Riipinen et al., 2011; Yu, 2011; Zhang et al., 2012).

Neither approach fully describes the behaviour of SOA; the kinetic approach neglects the re-evaporation of semivolatile organics whilst the thermodynamic approach is unable to account for the observed growth of particles beyond the nucleation mode (Pierce et al., 2011, 2012; Riipinen et al., 2011; Yu, 2011). The results of laboratory experiments indicate the presence of both semi-volatile organic aerosol components that evaporate upon heating or dilution (e.g. Robinson et al., 2007) as well as highly oxidised compounds with extremely low volatilities (Ehn et al., 2014) in atmospherically relevant SOA particles.

The treatment of SOA in global aerosol models is summarised by Tsigaridis et al. (2014). Global aerosol models typically use either the thermodynamic (partitioning proportional to existing organic mass; e.g. Chung and Seinfeld, 2002; Heald et al., 2008; Pye and Seinfeld, 2010; O'Donnell et al., 2011) or the kinetic (condensation proportional to particle surface area; e.g. Spracklen et al., 2006; Makkonen et al., 2009, 2012; Mann et al., 2010; D'Andrea et al., 2015) assumptions described above. Riipinen et al. (2011) and D'Andrea et al. (2013) both found that the simulated global annual mean concentration of $\mathrm{CCN}$-sized particles increased by approximately $10 \%$ when the kinetic (rather than mass-based) assumption was used for SOA, with regional increases of over $50 \%$. Yu (2011) found that allowing successive stages of oxidation to occur, and the generation of nonvolatile products which were distributed according to the kinetic approach, increased simulated surface level CCN concentrations by $5-50 \%$ over a version of the same model in which only an equilibrium approach was taken.

Previous modelling studies have quantified the cloud albedo effect, or first AIE, of biogenic SOA, estimating global annual mean values that span from positive $\left(+0.23 \mathrm{~W} \mathrm{~m}^{-2}\right.$; O'Donnell et al., 2011) to negative (e.g. $-0.02 \mathrm{~W} \mathrm{~m}^{-2}$ (Rap et al., 2013) and $-0.77 \mathrm{~W} \mathrm{~m}^{-2}$ (Scott et al., 2014)). One difference between these studies is the method by which they represent the condensation of SOA, with O'Donnell et al. (2011) applying a mass-based approach to partitioning, whereas the other studies used the kinetic approach. We hypothesise that uncertainty in the sign and magnitude of the first AIE due to biogenic SOA may, in part, be due to the different approaches used to distribute SOA amongst the existing aerosol population.

Conversely, we hypothesise that the direct radiative effect (DRE) due to biogenic SOA is less sensitive to the way in which secondary organic material is partitioned across the size distribution. Previous studies agree on a negative global annual mean DRE due to biogenic SOA: $-0.29 \mathrm{~W} \mathrm{~m}^{-2}$ (clear-sky; O'Donnell et al., 2011), $-0.13 \mathrm{~W} \mathrm{~m}^{-2}$ (all-sky; Rap et al., 2013), $-0.17 \mathrm{~W} \mathrm{~m}^{-2}$ (all-sky; Unger, 2014) and $-0.18 \mathrm{~W} \mathrm{~m}^{-2}$ (all-sky; Scott et al., 2014). Rap et al. (2013) explored the radiative effects associated with several natural aerosol sources and demonstrated that the DRE responds linearly to changes in emission source strength and is less sensitive to microphysical complexities than the first AIE.

Here we use a global aerosol microphysics model and offline radiative transfer model to explore how the assumed behaviour of secondary organic material affects simulated changes in $\mathrm{CCN}$-sized particles and, for the first time, CDNC and the radiative effects of biogenic SOA.

\section{Method}

\subsection{GLObal Model of Aerosol Processes (GLOMAP)}

We use GLOMAP-mode (Mann et al., 2010), which is an extension to the TOMCAT model (Chipperfield, 2006). Here we use the model with a horizontal resolution of $2.8^{\circ} \times 2.8^{\circ}$ with $31 \sigma$-pressure levels from the surface to $10 \mathrm{hPa}$. Meteorology is obtained from European Centre for Medium-Range 
Weather Forecasts (ECMWF) reanalyses at 6-hourly intervals and cloud fields from the International Satellite Cloud Climatology Project (ISCCP) archive (Rossow and Schiffer, 1999). The particle component masses and number concentrations are simulated in five log-normal size modes: four hydrophilic (nucleation, Aitken, accumulation and coarse), and a non-hydrophilic Aitken mode. Material in the particlephase is classified into four components: sulfate, black carbon, particulate organic matter and sea salt; this version of GLOMAP-mode does not include nitrate or ammonium aerosol. GLOMAP includes representations of nucleation, particle growth via coagulation, condensation and cloud processing, wet and dry deposition and in/below cloud scavenging. Operator splitting is used to calculate the different microphysical processes: condensation is calculated followed by nucleation then coagulation with a time step of $3 \mathrm{~min}$; Spracklen et al. (2005) found that shortening the length of the time step, and changing the order of operations altered particle concentrations by less than $5 \%$.

We prescribe 6-hourly mean offline oxidant $\left(\mathrm{OH}, \mathrm{O}_{3}\right.$, $\mathrm{NO}_{3}, \mathrm{HO}_{2}, \mathrm{H}_{2} \mathrm{O}_{2}$ ) concentrations, linearly interpolated to the model time step, from a previous TOMCAT simulation (Arnold et al., 2005). Monoterpene emissions are taken from the Global Emissions InitiAtive (GEIA) database (Guenther et al., 1995) and secondary organic material is generated at a fixed molar yield $(13 \%)$ from the oxidation of monoterpenes by $\mathrm{O}_{3}, \mathrm{OH}$ and $\mathrm{NO}_{3}$; producing approximately $20 \mathrm{Tg}(\mathrm{SOA}) \mathrm{a}^{-1}$. The inclusion of monoterpene emissions only will likely lead to an underestimate in the amount of SOA produced in our model simulations; the use of offline oxidants means that we do not simulate the feedback on oxidant concentrations due to monoterpene emission. Further details of this model set-up are given in Scott et al. (2014). In previous work (Mann et al., 2012) it has been demonstrated that the modal version of the model we use here is able to accurately simulate the aerosol size distribution simulated by a sectional version of the model (Spracklen et al., 2005). We have previously evaluated GLOMAP against observations of total particle number (Spracklen et al., 2010; Mann et al., 2012; Riccobono et al., 2014) and CCN concentrations (Spracklen et al., 2011; Mann et al., 2012; Schmidt et al., 2012; Scott et al., 2014).

\subsubsection{New particle formation}

All model experiments include a representation of binary homogeneous nucleation, which simulates the formation of particles from $\mathrm{H}_{2} \mathrm{SO}_{4}$ and $\mathrm{H}_{2} \mathrm{O}$; this occurs predominantly in the free troposphere and is parameterised according to Kulmala et al. (1998). One set of experiments (ACT; Table 1) use an empirically derived mechanism for the activation rate $\left(J_{\mathrm{ACT}}^{*}\right)$ of $\mathrm{H}_{2} \mathrm{SO}_{4}$ clusters in the boundary layer (Eq. 1; Kulmala et al., 2006), with a value for $A$ of $2 \times 10^{-6} \mathrm{~s}^{-1}$ (Sihto et al., 2006).
$J_{\mathrm{ACT}}^{*}=A\left[\mathrm{H}_{2} \mathrm{SO}_{4}\right]$

In a second set of experiments (ORG; Table 1), new particle formation is parameterised according to Metzger et al. (2010). In these simulations, the cluster formation rate ( $\left.J_{\mathrm{ORG}}^{*}\right)$ is calculated according to Eq. (2), where $S_{\text {org }}$ represents monoterpene oxidation products and $k=5 \times 10^{-13} \mathrm{~s}^{-1}$ (Metzger et al., 2010). In a sensitivity study (ORG_x10) we examine the impact of using a higher rate coefficient of $5 \times 10^{-12} \mathrm{~s}^{-1}$. Spatial variability in simulated $S_{\text {org }}$ concentration and calculated $J^{*}$ is shown in Figs. S1 and S2 in the Supplement respectively.

$J_{\mathrm{ORG}}^{*}=k\left[\mathrm{H}_{2} \mathrm{SO}_{4}\right]\left[S_{\mathrm{org}}\right]$

The initial stages of cluster growth are not simulated explicitly; rather, the approximation of Kerminen and Kulmala (2002) as given in Eq. (3) is used to determine the production rate $\left(J_{\mathrm{m}}\right)$ of particles at a measurable size (taken as $\left.d_{\mathrm{m}}=3 \mathrm{~nm}\right)$. The cluster dry diameter $\left(d^{*}\right)$ is taken as $0.8 \mathrm{~nm}$ for $J_{\mathrm{ACT}}^{*}$ and $1.5 \mathrm{~nm}$ for $J_{\mathrm{ORG}}^{*}$ (Metzger et al., 2010).

$J_{\mathrm{m}}=J^{*} \exp \left[0.23\left(\frac{1}{d_{\mathrm{m}}}-\frac{1}{d^{*}}\right) \frac{\mathrm{CS}}{\mathrm{GR}}\right]$

$J_{\mathrm{m}}$ allows the growth of newly formed clusters (up to $d_{\mathrm{m}}$ ) at a constant growth rate (GR); here GR is proportional to the gas-phase concentration of sulfuric acid, but other species could also contribute to growth at this size (Yli-Juuti et al., 2011; Kulmala et al., 2013). $J_{\mathrm{m}}$ also accounts for the scavenging of newly formed clusters by larger particles; the reduced condensation sink $\left(\mathrm{CS}^{\prime}\right)$ is calculated by integrating over the aerosol size modes, following Kulmala et al. (2001).

\subsubsection{Partitioning of secondary organic material}

The rate of change of gas-phase molecular concentration of organics $\left(S_{\text {org }}\right)$ due to condensation is calculated as in Eq. (4) where $C_{i}$ is the condensation coefficient for each mode $i$ (Eq. 5) and $N_{i}$ is the corresponding particle number concentration. $C_{i}$ is calculated for each mode $i$ as described in Mann et al. (2010) using the diffusion coefficient for a typical gasphase $\alpha$-pinene oxidation product in air $\left(D_{\mathrm{S}}\right)$ and the condensation sink radius $\left(\overline{r_{i, \text { cond }}}\right.$, calculated as in Eq. A1 of Mann et al., 2012, which is based on Lehtinen et al., 2003). $C_{i}$ is corrected for molecular effects and limitations in interfacial mass transport by the terms $F\left(K n_{i}\right)$ and $A\left(K n_{i}\right)$ respectively (Eqs. 6 and 7), where $s$ is the accommodation coefficient, or sticking efficiency. Here we assume a value of $s$ equal to 1; therefore $A\left(K n_{i}\right)$ is unity in this case. $K n_{i}$ is the Knudsen number for each mode $i$ (Eq. 8), calculated using the mean free path of the relevant condensable gas in air ( $\left.\mathrm{MFP}_{\text {gas }}\right)$. 


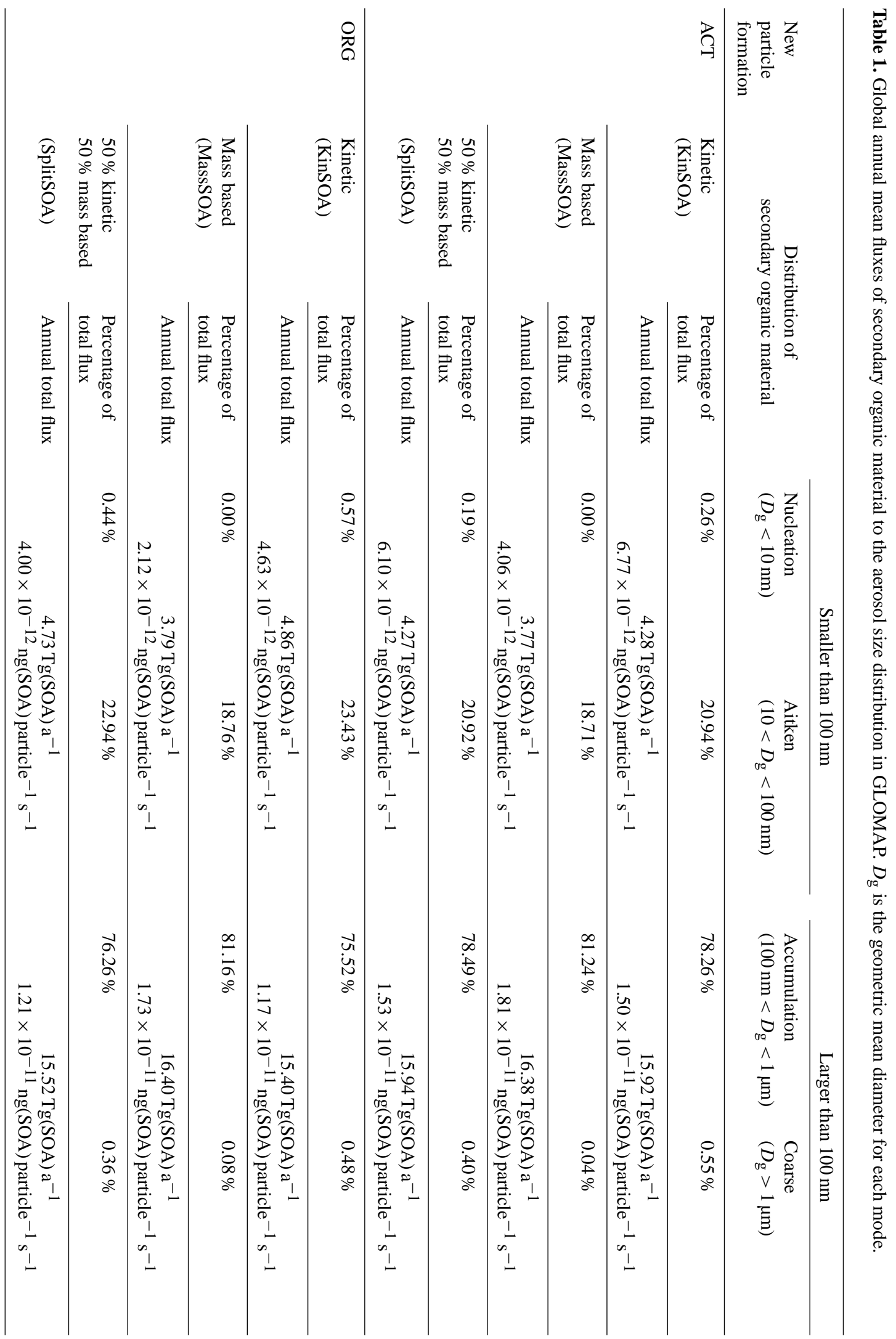




$$
\begin{aligned}
& \frac{\mathrm{d} S_{\text {org }}}{\mathrm{d} t}=-\left(\sum_{i} C_{i} N_{i}\right) S_{\text {org }} \\
& C_{i}=4 \pi D_{s} \overline{r_{i, \text { cond }}} F\left(K n_{i}\right) A\left(K n_{i}\right) \\
& F\left(K n_{i}\right)=\frac{1+K n_{i}}{1+1.71 K n_{i}+1.33\left(K n_{i}\right)^{2}} \\
& A\left(K n_{i}\right)=\frac{1}{1+1.33 K n_{i} F\left(K n_{i}\right)\left(\frac{1}{s}-1\right)} \\
& K n_{i}=\frac{\text { MFP }_{\text {gas }}}{\overline{r_{i, \text { cond }}}}
\end{aligned}
$$

We apply two different approaches to distribute SOA across the pre-existing aerosol size distribution. The rate of SOA condensation $\left(\mathrm{d} S_{\text {org }} / \mathrm{d} t\right)$ is identical in both approaches. In GLOMAP the standard approach is to assume secondary organic mass $\left(M_{\mathrm{SOA}}\right)$ condenses as if it were non-volatile to the Fuchs-corrected surface area as in Eq. (9); we refer to this as the "kinetic" approach.

$$
\frac{\mathrm{d} M_{\mathrm{SOA}_{i}}}{\mathrm{~d} t}=\frac{C_{i} N_{i}}{\sum_{i=1,5} C_{i} N} \times \frac{\mathrm{d} S_{\mathrm{org}}}{\mathrm{d} t}
$$

Here, we apply a second approach in which the amount of secondary organic material entering the aerosol phase is partitioned between the size modes according to Eq. (10), mimicking the thermodynamic approach; we refer to this as the "mass-based" approach. $M_{\mathrm{OA} i}$ is the pre-existing organic mass in mode $i$.

$$
\frac{\mathrm{d} M_{\mathrm{SOA}_{i}}}{\mathrm{~d} t}=\frac{M_{\mathrm{OA}_{i}}}{\sum_{i=1,5} M_{\mathrm{OA}_{i}}} \times \frac{\mathrm{d} S_{\mathrm{org}}}{\mathrm{d} t}
$$

We complete one simulation without biogenic SOA (NoSOA), as well as simulations with biogenic SOA distributed according to the kinetic approach (KinSOA), the mass-based approach (MassSOA), and a simulation in which $50 \%$ of the SOA mass is distributed according to each approach (SplitSOA). We note that the KinSOA simulation matches the approach used in a wide range of recent studies with global aerosol models (Spracklen et al., 2006; Makkonen et al., 2009; Pierce and Adams, 2009; Mann et al., 2010; D'Andrea et al., 2015).

GLOMAP-mode uses a two-moment modal approach, within which mode number and mass concentrations vary but the mode width is held fixed. Following condensation, the particle number concentration for a mode is held constant and the new geometric mean diameter for the mode is calculated according to the updated volume per particle (Mann et al., 2010). Since the mode width is held fixed, this approach will not capture potential changes to the distribution of material within a mode following condensation.
Because our aim is to quantify the impact of changes in the size of particles to which the SOA condenses, we otherwise treat SOA identically between the two different approaches and do not allow SOA to re-partition into the gas phase. To isolate the impact of the condensation of secondary organic material the SOA yield, the oxidant chemistry and the SOA condensation rate was identical in all simulations.

\subsection{Calculation of radiative effects}

The changes to CDNC due to the inclusion of biogenic SOA (i.e. KinSOA - NoSOA) are calculated from the monthly mean aerosol distribution, using the parameterisation developed by Nenes and Seinfeld (2003), Fountoukis and Nenes (2005) and Barahona et al. (2010); assuming a globally uniform updraught velocity of $0.2 \mathrm{~m} \mathrm{~s}^{-1}$.

The first AIE due to biogenic SOA is then determined using the offline radiative transfer model of Edwards and Slingo (1996) with nine bands in the longwave (LW) and six bands in the shortwave (SW); a monthly mean climatology based on ECMWF reanalysis data and cloud fields for the year 2000 from the ISCCP-D2 archive (Rossow and Schiffer, 1999) is used. To calculate the first AIE, a uniform control cloud droplet effective radius $\left(r_{\mathrm{e} 1}\right)$ of $10 \mu \mathrm{m}$ is assumed to maintain consistency with the ISCCP derivation of the liquid water path, and for each perturbation experiment the effective radius $\left(r_{\mathrm{e} 2}\right)$ is calculated as in Eq. (11) from monthly mean cloud droplet number fields $\mathrm{CDNC}_{1}$ and $\mathrm{CDNC}_{2}$ respectively (where $\mathrm{CDNC}_{1}$ represents the simulation including $\mathrm{SOA}$, and $\mathrm{CDNC}_{2}$ represents the simulation with no SOA).

$r_{\mathrm{e} 2}=r_{\mathrm{e} 1} \times\left[\frac{\mathrm{CDNC}_{1}}{\mathrm{CDNC}_{2}}\right]^{\frac{1}{3}}$

The first AIE of biogenic SOA is then calculated by comparing net $(\mathrm{SW}+\mathrm{LW})$ radiative fluxes using the varying $r_{\mathrm{e} 2}$ values derived for each perturbation experiment to those of the control simulation with fixed $r_{\mathrm{e} 1}$. In these offline experiments, we do not calculate the second aerosol indirect (cloud lifetime) effect.

To determine the DRE, following the methodology described in Rap et al. (2013), the radiative transfer model is used to calculate the difference in net top-of-atmosphere all-sky radiative flux between experiments including SOA and the equivalent experiments without SOA. Aerosol optical properties are calculated from the monthly mean aerosol distribution. The refractive index for each mode is calculated as the volume-weighted mean refractive index of the components present (values for which are given at $550 \mathrm{~nm}$ in Table A1 of Bellouin et al., 2011), including water for the soluble modes. The optical properties (scattering and absorption coefficients together with the dimensionless asymmetry parameter) are then obtained from look-up tables of all realistic 
combinations of refractive index and Mie parameter, as described in Bellouin et al. (2013).

\section{Results}

Table 1 summarises how the treatment of SOA condensation in GLOMAP impacts the global flux of secondary organic material to the aerosol size distribution. The total global flux of secondary organic material to the particle phase is the same in each approach $\left(\sim 20.2 \mathrm{Tg}(\mathrm{SOA}) \mathrm{a}^{-1}\right)$, but there are important changes to how the material is distributed across particles of different sizes. When the mass-based approach is applied, no SOA is added to the nucleation mode. Rather, SOA is added to larger particles with greater existing organic mass (more than $80 \%$ to particles with dry diameter greater than $100 \mathrm{~nm}$, less than $20 \%$ to particles with dry diameter between 10 and $100 \mathrm{~nm}$ ). Under the kinetic approach, most of the secondary organic material also condenses on the larger particles $(\sim 76-78 \%$ to particles with diameter greater than $100 \mathrm{~nm}, \sim 21-23 \%$ to particles with dry diameter between 10 and $100 \mathrm{~nm})$. Additionally, a small fraction (0.26-0.57\%) of secondary organic material is added to the nucleation mode (i.e. particles with diameter less than $10 \mathrm{~nm}$ ), under the kinetic approach. As we show below, this small amount of SOA (0.05-0.11 Tg(SOA) $\left.\mathrm{a}^{-1}\right)$ adding to nucleation mode particles has important implications for the aerosol size distribution.

Figure 1 compares simulated and observed aerosol number size distributions at two forest locations: Hyytiälä, Finland $\left(24.3^{\circ} \mathrm{E}, 61.9^{\circ} \mathrm{N}\right.$; described in Hari and Kulmala, 2005), during the northern hemispheric summertime and Manaus, Brazil $\left(60.2^{\circ} \mathrm{W}, 2.6^{\circ} \mathrm{S}\right.$; described in Martin et al., 2010, and Rizzo et al., 2013), during the wet season. From Manaus, we include in our wet season mean only scanning mobility particle sizer data that could be validated (and agreed to within $15 \%$ ) by comparison to particle number concentrations measured with a condensation particle counter. In boreal and tropical rainforests, the aerosol size distribution will be sensitive to a range of processes including particle formation rates, amount of SOA, the characteristics of primary particles and in-cloud processing (e.g. Spracklen et al., 2008, 2010; Martin et al., 2010; Reddington et al., 2011). Our intention here is to demonstrate that the aerosol size distribution simulated by GLOMAP is also sensitive to the treatment of SOA condensation.

When the mass-based approach (dashed lines in Fig. 1) is applied, the model simulates high concentrations of nucleation mode particles (smaller than $10 \mathrm{~nm}$ dry diameter). Under this approach no organic material condenses on these small particles and their growth is slow since it is limited by the availability of sulfuric acid (Riipinen et al., 2011). This slow growth rate means few particles can grow to larger sizes and the number of particles simulated between 30 and $100 \mathrm{~nm}$ diameter is far less than observed at both sites.
When the kinetic approach is applied, a small amount of SOA condenses onto particles in the nucleation mode $(0.26 \%$ of the total global flux for ACT and $0.57 \%$ for ORG; Table 1), increasing the growth rate of these small particles. At Hyytiälä, the kinetic approach results in a greater number of particles in the 30-100 nm size range compared to the mass-based approach, improving the match against observations over this size range (KinSOA; full lines in Fig. 1). At Manaus, the number of particles in the $30-100 \mathrm{~nm}$ range is underestimated with either approach. Under the kinetic approach, the number of particles between 100 and $200 \mathrm{~nm}$ is greater than observed, when the organically mediated new particle formation mechanism is used (KinSOA_ORG), suggesting that the growth rate of particles in the Aitken mode may be overestimated under these conditions.

At both sites, we simulate a similar size distribution when we assume either completely kinetic condensation or a combination of the kinetic and mass-based approaches (full or dotted red lines in Fig. 1). In the SplitSOA experiments, some secondary organic material is able to condense onto newly formed particles $(0.19 \%$ of the total flux for ACT and $0.44 \%$ for ORG; Table 1), resulting in a size distribution similar to that generated by the kinetic approach (SplitSOA; dotted lines in Fig. 1). This implies that it is not necessary to assume that all of the organic material generated has an extremely low volatility in order to account for the growth of particles to $\mathrm{CCN}$ relevant sizes, but that some fraction of the SOA does need to be treated in this way, consistent with the findings of Kulmala et al. (2013). The same relative response to the kinetic and mass-based approaches was documented by D'Andrea et al. (2013) and is consistent with Yu (2011), who combined the kinetic condensation of low-volatility organics with the equilibrium partitioning of semi-volatile organics.

\subsection{Changes to cloud droplet number concentration}

Table 2 reports the simulated changes to global CDNC due to biogenic SOA under the kinetic, mass-based and split approaches for both nucleation mechanisms. As we have reported previously, the impact of biogenic SOA on CDNC strongly depends on the nucleation mechanism used in the model, with the largest impact on CDNC simulated with an organically mediated new particle formation mechanism (Scott et al., 2014). We find that for both nucleation mechanisms, biogenic SOA leads to a larger global annual mean increase in CDNC under the kinetic condensation approach compared to the mass-based approach. With the ACT nucleation mechanism, GLOMAP simulates a $3.4 \%$ increase in global annual mean CDNC with kinetic condensation but only a $1.4 \%$ increase when the mass-based approach is used. Similarly, with the ORG nucleation mechanism, GLOMAP simulates a $21.1 \%$ increase in global annual mean CDNC with kinetic condensation and a $16.8 \%$ increase when the mass-based approach is used; the same relative response is observed in our sensitivity study (ORG_x10), in which the 


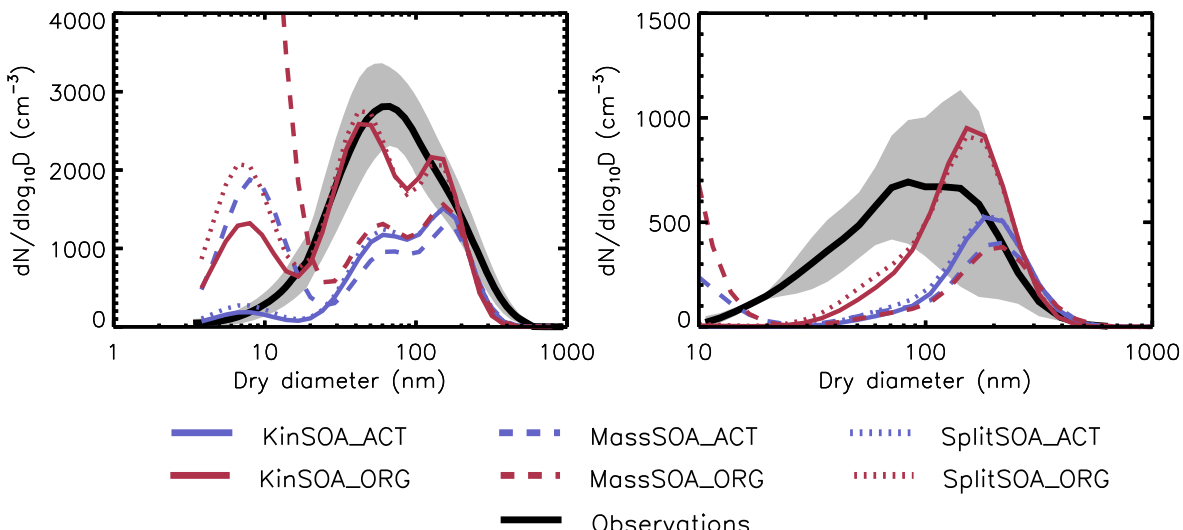

Figure 1. Simulated and observed mean aerosol number size distributions at two forested sites. (Left) Hyytiälä, Finland, during JuneJuly-August (multi-annual; 1996-2006). (Right) Manaus, Brazil, during the wet season (multi-annual; January-June, 2008-2009). The grey shaded regions indicate \pm 1 standard deviation from the seasonal mean, calculated from the observed monthly mean size distributions (over all years). In each figure, simulations show the sensitivity to the nucleation mechanism (activation (blue) and organically mediated (red)) and condensation assumption (kinetic (solid), mass-based (dashed) and 50\% split kinetic and mass-based approaches (dotted)).

Table 2. Global annual mean change to CDNC, calculated using a globally uniform updraught velocity of $0.2 \mathrm{~ms}^{-1}$, in the model level corresponding to low-level cloud base (mean pressure of approx. $900 \mathrm{hPa}$ ), first AIE and DRE due to biogenic SOA in GLOMAP using the kinetic and mass-based approaches.

\begin{tabular}{|c|c|c|c|c|c|}
\hline $\begin{array}{l}\text { Nucleation } \\
\text { mechanism }\end{array}$ & $\begin{array}{l}\text { Background } \\
\text { (without biogenic SOA) } \\
\text { global annual } \\
\text { mean CDNC }\left(\mathrm{cm}^{-3}\right)\end{array}$ & $\begin{array}{l}\text { Distribution of } \\
\text { secondary organic } \\
\text { material }\end{array}$ & $\triangle \mathrm{CDNC}$ & $\begin{array}{r}\text { AIE } \\
\left(\mathrm{W} \mathrm{m}^{-2}\right)\end{array}$ & $\begin{array}{r}\text { DRE } \\
\left(\mathrm{W} \mathrm{m}^{-2}\right)\end{array}$ \\
\hline ACT & 185.2 & $\begin{array}{l}\text { KinSOA } \\
\text { MassSOA } \\
\text { SplitSOA }\end{array}$ & $\begin{array}{l}+6.3(+3.4 \%) \\
+2.6(+1.4 \%) \\
+5.9(+3.2 \%)\end{array}$ & $\begin{array}{l}-0.07 \\
+0.01 \\
-0.05\end{array}$ & $\begin{array}{l}-0.10 \\
-0.11 \\
-0.11\end{array}$ \\
\hline ORG & 165.2 & $\begin{array}{l}\text { KinSOA } \\
\text { MassSOA } \\
\text { SplitSOA }\end{array}$ & $\begin{array}{l}+34.8(+21.1 \%) \\
+27.8(+16.8 \%) \\
+33.77(+20.4 \%)\end{array}$ & $\begin{array}{l}-0.66 \\
-0.50 \\
-0.63\end{array}$ & $\begin{array}{l}-0.09 \\
-0.08 \\
-0.09\end{array}$ \\
\hline ORG_x10 & 165.2 & $\begin{array}{l}\text { KinSOA } \\
\text { MassSOA } \\
\text { SplitSOA }\end{array}$ & $\begin{array}{l}+41.5(+25.1 \%) \\
+33.0(+20.0 \%) \\
+40.3(+24.4 \%)\end{array}$ & $\begin{array}{l}-0.78 \\
-0.59 \\
-0.75\end{array}$ & $\begin{array}{l}-0.08 \\
-0.08 \\
-0.09\end{array}$ \\
\hline
\end{tabular}

organically mediated nucleation rate is a factor of 10 higher. The SplitSOA approach increases the global annual mean CDNC by almost as much as the kinetic approach $(+3.2 \%$ for ACT and $+20.4 \%$ for ORG) because only a small amount of SOA is required to allow the smallest particles to grow sufficiently.

Simulated changes to CDNC (Fig. 2) are not restricted to the areas over which biogenic SOA is generated or proportional to the amount of SOA being generated, as discussed in Scott et al. (2014). Under the kinetic approach, GLOMAP simulates large fractional increases to CDNC over boreal regions and southern hemispheric oceans (greater than $20 \%$ for ACT and over $100 \%$ for ORG; Fig. 2). Using the mass-based approach, the growth of particles to CCN-relevant size is sup- pressed and fewer regions experience such large increases in CDNC in response to the inclusion of biogenic SOA.

The inclusion of biogenic SOA can induce decreases in simulated CDNC due to an enhanced rate of ageing/scavenging of initially hydrophobic particles or the suppression of nucleation in the free troposphere (and subsequent entrainment back into the boundary layer) due to an increased condensation sink at the surface (Scott et al., 2014). When the ACT mechanism for new particle formation is used with the kinetic approach, these effects combine to give small decreases to CDNC over tropical ocean regions (Fig. 2a); when the mass-based approach is used, much larger ocean regions experience a decrease in CDNC (Fig. 2b). In the ORG simulations, the contribution of organic oxidation products 
a) ACT Kinetic

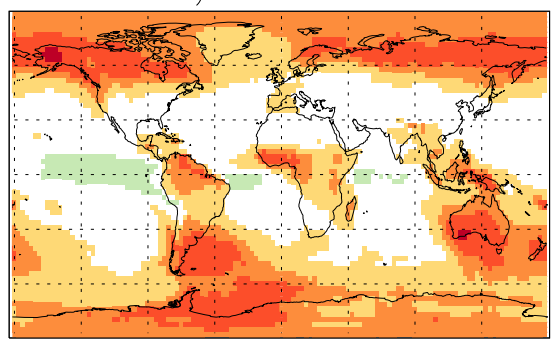

c) ORG Kinetic

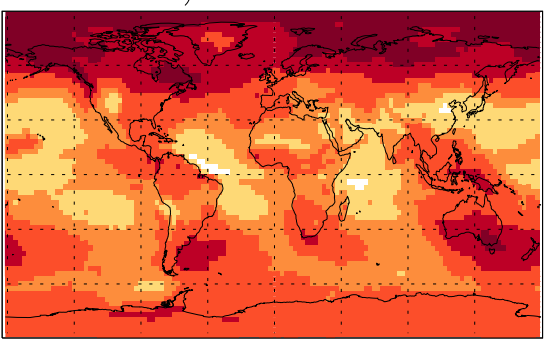

b) ACT Mass based

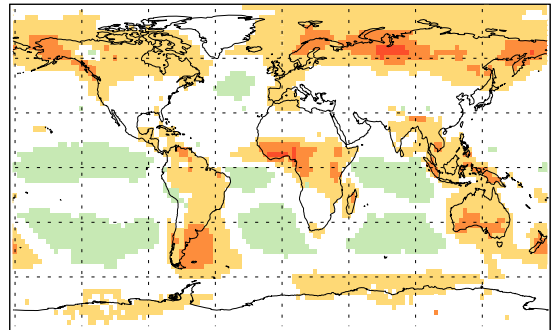

d) ORG Mass based

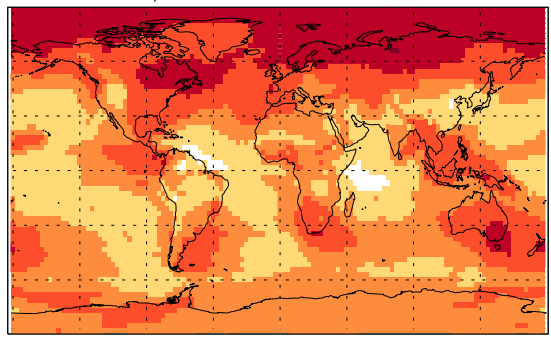

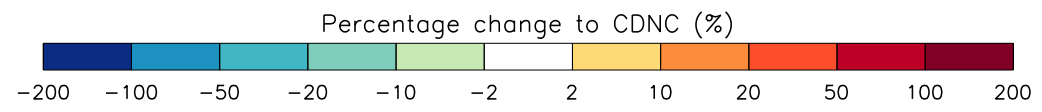

Figure 2. Annual mean percentage change to CDNC (using a uniform updraught velocity of $0.2 \mathrm{~m} \mathrm{~s}^{-1}$ ) from biogenic SOA in GLOMAP, in the model level which corresponds to low-level cloud base (mean pressure of approximately $900 \mathrm{hPa}$ ); SOA is distributed according to the kinetic approach (a and $\mathbf{c}$ ) and the mass-based approach (b and d). Simulations use either an activation (a and b) or organically mediated (c and d) new particle formation mechanism.

to new particle formation is sufficient to prevent any regional decreases in CDNC under either approach (Fig. 2c and d).

To examine the sensitivity of this response to updraught velocity, CDNC were calculated at five globally uniform updraught velocities, from 0.1 to $0.5 \mathrm{~m} \mathrm{~s}^{-1}$, for the ACT set of experiments (Table 3). Under both approaches to SOA partitioning, increasing the updraught velocity increases the absolute and fractional change in $\mathrm{CDNC}$ at low-level cloud base due to biogenic SOA; however, the relative kinetic to massbased response remains consistent.

\subsection{First aerosol indirect effect}

We explored the impact of the condensation approach on the first AIE due to biogenic SOA and report the global annual mean values in Table 2; Fig. 3 shows the spatial patterns in annual mean first AIE for each nucleation mechanism and partitioning approach. The global annual mean first AIE is calculated for an updraft velocity of $0.2 \mathrm{~m} \mathrm{~s}^{-1}$; in Table 3 we show consistent results for a range of updraft velocities between 0.1 and $0.5 \mathrm{~m} \mathrm{~s}^{-1}$.

Increases in CDNC lead to a negative first AIE (i.e. a cooling effect), and decreases in CDNC lead to a positive first AIE (i.e. a warming effect). When the ACT new particle formation mechanism is used, the kinetic approach gives a negative global annual mean first AIE of $-0.07 \mathrm{~W} \mathrm{~m}^{-2}$, with a negative first $\mathrm{AIE}$ in regions of $\mathrm{CDNC}$ increase and a posi- tive first AIE in regions of CDNC decrease (Fig. 3a). When the ACT mechanism is used with the mass-based approach, spatially extensive decreases in CDNC (as compared to the kinetic approach) lead to large regions where a positive first AIE is simulated and a positive global annual mean first AIE $\left(+0.01 \mathrm{~W} \mathrm{~m}^{-2}\right)$ due to biogenic SOA (Fig. 3b).

When the ORG mechanism is used with the kinetic approach, the inclusion of biogenic SOA generates a global annual mean first AIE of $-0.66 \mathrm{~W} \mathrm{~m}^{-2}$ due to widespread increases in CDNC (Fig. 2c), which is reduced to $-0.50 \mathrm{~W} \mathrm{~m}^{-2}$ under the mass-based approach (Table 2). A global annual mean negative first AIE is maintained under the mass-based approach because the contribution of organic oxidation products to new particle formation is sufficient to outweigh the impact of suppressed growth on CDNC (Fig. 2d). The same relative response between the two partitioning approaches $\left(-0.78 \mathrm{~W} \mathrm{~m}^{-2}\right.$ for kinetic, as compared to $-0.59 \mathrm{~W} \mathrm{~m}^{-2}$ for the mass-based approach) is observed for our ORG_x10 sensitivity simulations, in which the organically mediated nucleation rate is a factor of 10 higher.

For both nucleation mechanisms, the SplitSOA approach gives a negative first AIE $\left(-0.05 \mathrm{~W} \mathrm{~m}^{-2}\right.$ for ACT and $-0.63 \mathrm{~W} \mathrm{~m}^{-2}$ for $\mathrm{ORG}$ ) of similar magnitude to the $\mathrm{ki}$ netic approach due to similar changes to global annual mean CDNC. 
a) ACT Kinetic

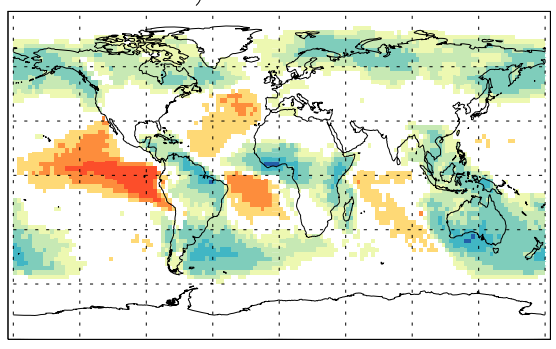

c) ORG Kinetic

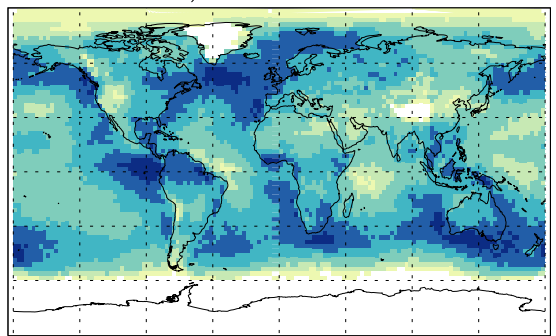

b) ACT Mass based

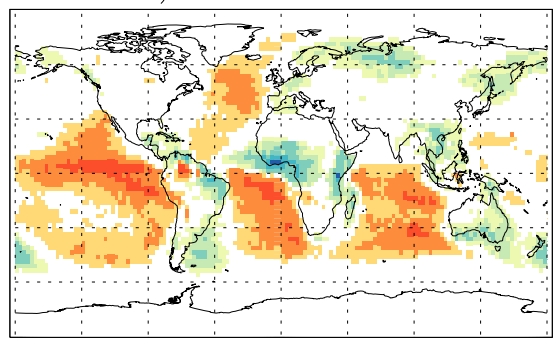

d) ORG Mass based

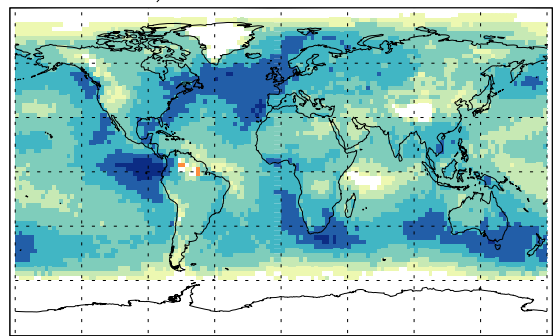

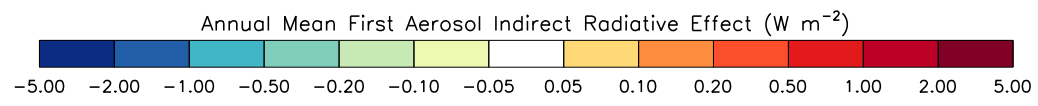

Figure 3. Annual mean first AIE $\left(\mathrm{W} \mathrm{m}^{-2}\right)$ from biogenic SOA in GLOMAP when SOA is distributed according to the kinetic approach (a and $\mathbf{c})$ and the mass-based approach (b and d). Simulations use either an activation (a and $\mathbf{b})$ or organically mediated (c and d) new particle formation mechanism.

Table 3. Global annual mean change to cloud droplet number concentration (CDNC), calculated using five globally uniform updraught velocities, in the model level which corresponds to low-level cloud base (mean pressure of approximately $900 \mathrm{hPa}$ ), and first aerosol indirect effect (AIE), reported to two decimal places, resulting from the inclusion of biogenic SOA in GLOMAP using the kinetic and mass-based approaches. The mean values are calculated assuming that all updraught velocities are equally likely.

\begin{tabular}{|c|c|c|c|c|c|}
\hline \multirow[t]{3}{*}{ Nucleation mechanism } & \multirow[t]{3}{*}{ Updraught velocity $\left(\mathrm{m} \mathrm{s}^{-1}\right)$} & \multicolumn{4}{|c|}{ Distribution of secondary organic material } \\
\hline & & \multicolumn{2}{|c|}{ KinSOA } & \multicolumn{2}{|c|}{ MassSOA } \\
\hline & & $\Delta \mathrm{CDNC}\left(\mathrm{cm}^{-3}\right)$ & $\operatorname{AIE}\left(\mathrm{W} \mathrm{m}^{-2}\right)$ & $\Delta \mathrm{CDNC}\left(\mathrm{cm}^{-3}\right)$ & $\operatorname{AIE}\left(\mathrm{W} \mathrm{m}^{-2}\right)$ \\
\hline \multirow[t]{6}{*}{ ACT } & 0.1 & $+2.7(+2.0 \%)$ & -0.04 & $+0.6(+0.5 \%)$ & +0.02 \\
\hline & 0.2 & $+6.3(+3.4 \%)$ & -0.07 & $+2.6(+1.4 \%)$ & +0.01 \\
\hline & 0.3 & $+9.1(+4.3 \%)$ & -0.08 & $+4.4(+2.1 \%)$ & 0.00 \\
\hline & 0.4 & $+11.3(+4.9 \%)$ & -0.08 & $+6.0(+2.6 \%)$ & -0.01 \\
\hline & 0.5 & $+12.9(+5.3 \%)$ & -0.08 & $+7.2(+3.0 \%)$ & -0.01 \\
\hline & Mean & $+8.4(+4.0 \%)$ & -0.07 & $+4.2(+1.9 \%)$ & +0.004 \\
\hline
\end{tabular}

\subsection{Direct radiative effect}

The direct radiative effect is less sensitive to the distribution of secondary organic material across the aerosol size distribution (Table 2). When the ACT new particle formation mechanism is used, the kinetic approach gives a global annual mean DRE of $-0.10 \mathrm{~W} \mathrm{~m}^{-2}$, as compared to $-0.11 \mathrm{~W} \mathrm{~m}^{-2}$ with the kinetic approach. When the ORG mechanism for new particle formation is used, the inclusion of biogenic SOA generates a global annual mean DRE that varies between -0.08 and $-0.09 \mathrm{~W} \mathrm{~m}^{-2}$ across all three approaches to partitioning.

This lack of sensitivity can be explained in part by the fact that, under the mass-based approach, the shift in SOA mass from smaller $(<100 \mathrm{~nm}$ dry diameter) to larger $(>100 \mathrm{~nm}$ dry diameter) particles represents a much smaller fractional change to the amount of SOA the larger particles receive. Using the ACT mechanism, particles greater than $100 \mathrm{~nm}$ dry diameter receive approximately $20 \%$ more secondary organic mass per particle under the mass-based approach, relative to the amount they received under the kinetic approach, 
whereas particles smaller than $100 \mathrm{~nm}$ dry diameter receive approximately $40 \%$ less secondary organic mass per particle under the mass-based approach, relative to the amount they received under the kinetic approach (Table 2).

\section{Conclusions}

Using a global aerosol microphysics model we have shown that the manner in which secondary organic material is added to the aerosol size distribution is important in determining its impact on the number and size of climatically relevant particles in the atmosphere. We tested two assumptions about the way secondary organic material is added to existing particles - a kinetic approach where material condenses according to the surface area of existing particles and a mass-based approach where the material condenses according to the organic mass present in existing particles. We calculate the impact of these assumptions on the direct radiative effect and first aerosol indirect effect due to biogenic secondary organic aerosol.

The kinetic approach to partitioning, which enables organic oxidation products to condense upon the smallest particles, facilitating their growth to larger sizes, increases global annual mean CDNC when either an activation or organically mediated new particle formation mechanism is applied (by $3.4 \%$ for ACT and $21.1 \%$ for ORG). These global annual mean increases in CDNC result in a negative global annual mean first AIE $\left(-0.07 \mathrm{~W} \mathrm{~m}^{-2}\right.$ for ACT and $-0.66 \mathrm{~W} \mathrm{~m}^{-2}$ for ORG).

Applying a mass-based approach to partitioning suppresses the growth of the smallest particles, resulting in a smaller global annual mean increase in CDNC $(+1.4 \%$ for $\mathrm{ACT}$ and $+16.8 \%$ for ORG). When an activation mechanism is applied to new particle formation, the mass-based approach results in a small positive first AIE $\left(+0.01 \mathrm{~W} \mathrm{~m}^{-2}\right)$ due to biogenic SOA. When an organically mediated new particle formation mechanism is applied, a negative first AIE is maintained because the contribution of organic oxidation products to new particle formation is sufficient to outweigh the impact of suppressed growth on CDNC, but the magnitude of the first AIE is reduced by $24 \%$ to $-0.50 \mathrm{~W} \mathrm{~m}^{-2}$; we see a consistent response when the organically mediated nucleation rate is a factor of 10 higher.

Neither approach adequately describes the complex behaviour of secondary organic material in the atmosphere. U1timately, a combination of thermodynamic and kinetic approaches will be required to accurately represent the behaviour of SOA in global models. Improving on existing first attempts, by e.g. Riipinen et al. (2011), Yu (2011) and the SplitSOA approach described here, will require a more detailed understanding of the pathways by which organic compounds of differing volatilities are generated and their relative contributions to the growth of particles of different sizes.

\author{
The Supplement related to this article is available online \\ at doi:10.5194/acp-15-12989-2015-supplement.
}

Acknowledgements. We acknowledge support from NERC (NE/H524673/1, NE/J004723/1, NE/G015015/1, NE/K015966/1), EPSRC (EP/I014721/1), ERC (227463-ATMNUCLE). Aerosol measurements at Hyytiälä were supported by the Academy of Finland Centre of Excellence (1118615 and 1127372), and the Cryosphere-Atmosphere Interactions in a Changing Arctic Climate (CRAICC) programme. Aerosol measurements in the Amazon were supported by Fundacao de Amparo a Pesquisa do Estado de Sao Paulo (FAPESP - AEROCLIMA 08/58100-2), Conselho Nacional de Desenvolvimento Científico $(\mathrm{CNPq})$ and European Integrated FP6 Project on Aerosol Cloud Climate and Air Quality Interactions (EUCAARI - 34684), under the scope of LBA experiment; we thank INPA (Instituto Nacional de Pesquisas da Amazonia) for the coordination work of the LBA Experiment.

Edited by: K. Tsigaridis

\section{References}

Arnold, S. R., Chipperfield, M. P., and Blitz, M. A.: A threedimensional model study of the effect of new temperaturedependent quantum yields for acetone photolysis, J. Geophys. Res., 110, D22305, doi:10.1029/2005jd005998, 2005.

Barahona, D., West, R. E. L., Stier, P., Romakkaniemi, S., Kokkola, H., and Nenes, A.: Comprehensively accounting for the effect of giant CCN in cloud activation parameterizations, Atmos. Chem. Phys., 10, 2467-2473, doi:10.5194/acp-10-2467-2010, 2010.

Bellouin, N., Rae, J., Jones, A., Johnson, C., Haywood, J., and Boucher, O.: Aerosol forcing in the Climate Model Intercomparison Project (CMIP5) simulations by HadGEM2-ES and the role of ammonium nitrate, J. Geophys. Res., 116, D20206, doi:10.1029/2011jd016074, 2011.

Bellouin, N., Mann, G. W., Woodhouse, M. T., Johnson, C., Carslaw, K. S., and Dalvi, M.: Impact of the modal aerosol scheme GLOMAP-mode on aerosol forcing in the Hadley Centre Global Environmental Model, Atmos. Chem. Phys., 13, 30273044, doi:10.5194/acp-13-3027-2013, 2013.

Chipperfield, M. P.: New version of the TOMCAT/SLIMCAT offline chemical transport model: Intercomparison of stratospheric tracer experiments, Q. J. Roy. Meteor. Soc., 132, 1179-1203, doi:10.1256/qj.05.51, 2006.

Chung, S. H. and Seinfeld, J. H.: Global distribution and climate forcing of carbonaceous aerosols, J. Geophys. Res., 107, 4407, doi:10.1029/2001jd001397, 2002.

D’Andrea, S. D., Häkkinen, S. A. K., Westervelt, D. M., Kuang, C., Levin, E. J. T., Kanawade, V. P., Leaitch, W. R., Spracklen, D. V., Riipinen, I., and Pierce, J. R.: Understanding global secondary organic aerosol amount and size-resolved condensational behavior, Atmos. Chem. Phys., 13, 11519-11534, doi:10.5194/acp-1311519-2013, 2013.

D’Andrea, S. D., Acosta Navarro, J. C., Farina, S. C., Scott, C. E., Rap, A., Farmer, D. K., Spracklen, D. V., Riipinen, I., and 
Pierce, J. R.: Aerosol size distribution and radiative forcing response to anthropogenically driven historical changes in biogenic secondary organic aerosol formation, Atmos. Chem. Phys., 15, 2247-2268, doi:10.5194/acp-15-2247-2015, 2015.

Donahue, N. M., Trump, E. R., Pierce, J. R., and Riipinen, I.: Theoretical constraints on pure vapor-pressure driven condensation of organics to ultrafine particles, Geophys. Res. Lett., 38, L16801, doi:10.1029/2011g1048115, 2011.

Edwards, J. M. and Slingo, A.: Studies with a flexible new radiation code. I: Choosing a configuration for a large-scale model, Q. J. Roy. Meteor. Soc., 122, 689-719, doi:10.1002/qj.49712253107, 1996.

Ehn, M., Thornton, J. A., Kleist, E., Sipila, M., Junninen, H., Pullinen, I., Springer, M., Rubach, F., Tillmann, R., Lee, B., LopezHilfiker, F., Andres, S., Acir, I.-H., Rissanen, M., Jokinen, T., Schobesberger, S., Kangasluoma, J., Kontkanen, J., Nieminen, T., Kurten, T., Nielsen, L. B., Jorgensen, S., Kjaergaard, H. G., Canagaratna, M., Maso, M. D., Berndt, T., Petaja, T., Wahner, A., Kerminen, V.-M., Kulmala, M., Worsnop, D. R., Wildt, J., and Mentel, T. F.: A large source of low-volatility secondary organic aerosol, Nature, 506, 476-479, doi:10.1038/nature13032, 2014.

Fiore, A. M., Naik, V., Spracklen, D. V., Steiner, A., Unger, N., Prather, M., Bergmann, D., Cameron-Smith, P. J., Cionni, I., Collins, W. J., Dalsoren, S., Eyring, V., Folberth, G. A., Ginoux, P., Horowitz, L. W., Josse, B., Lamarque, J.-F., MacKenzie, I. A., Nagashima, T., O’Connor, F. M., Righi, M., Rumbold, S. T., Shindell, D. T., Skeie, R. B., Sudo, K., Szopa, S., Takemura, T., and Zeng, G.: Global air quality and climate, Chem. Soc. Rev., 41, 6663-6683, doi:10.1039/c2cs35095e, 2012.

Fountoukis, C. and Nenes, A.: Continued development of a cloud droplet formation parameterization for global climate models, J. Geophys. Res., 110, D11212, doi:10.1029/2004jd005591, 2005.

Guenther, A., Hewitt, C. N., Erickson, D., Fall, R., Geron, C., Graedel, T., Harley, P., Klinger, L., Lerdau, M., McKay, W. A., Pierce, T., Scholes, B., Steinbrecher, R., Tallamraju, R., Taylor, J., and Zimmerman, P.: A global model of natural volatile organic compound emissions, J. Geophys. Res., 100, 8873-8892, doi:10.1029/94jd02950, 1995.

Guenther, A., Karl, T., Harley, P., Wiedinmyer, C., Palmer, P. I., and Geron, C.: Estimates of global terrestrial isoprene emissions using MEGAN (Model of Emissions of Gases and Aerosols from Nature), Atmos. Chem. Phys., 6, 3181-3210, doi:10.5194/acp-63181-2006, 2006.

Hari, P. and Kulmala, M.: Station for Measuring EcosystemAtmosphere Relations (SMEAR II), Boreal Environ. Res., 10, 315-322, 2005.

Heald, C. L., Henze, D. K., Horowitz, L. W., Feddema, J., Lamarque, J. F., Guenther, A., Hess, P. G., Vitt, F., Seinfeld, J. H., Goldstein, A. H., and Fung, I.: Predicted change in global secondary organic aerosol concentrations in response to future climate, emissions, and land use change, J. Geophys. Res., 113, D05211, doi:10.1029/2007jd009092, 2008.

Jimenez, J. L., Canagaratna, M. R., Donahue, N. M., Prevot, A. S. H., Zhang, Q., Kroll, J. H., DeCarlo, P. F., Allan, J. D., Coe, H., Ng, N. L., Aiken, A. C., Docherty, K. S., Ulbrich, I. M., Grieshop, A. P., Robinson, A. L., Duplissy, J., Smith, J. D., Wilson, K. R., Lanz, V. A., Hueglin, C., Sun, Y. L., Tian, J., Laaksonen, A., Raatikainen, T., Rautiainen, J., Vaattovaara, P., Ehn,
M., Kulmala, M., Tomlinson, J. M., Collins, D. R., Cubison, M. J., E., Dunlea, J., Huffman, J. A., Onasch, T. B., Alfarra, M. R., Williams, P. I., Bower, K., Kondo, Y., Schneider, J., Drewnick, F., Borrmann, S., Weimer, S., Demerjian, K., Salcedo, D., Cottrell, L., Griffin, R., Takami, A., Miyoshi, T., Hatakeyama, S., Shimono, A., Sun, J. Y., Zhang, Y. M., Dzepina, K., Kimmel, J. R., Sueper, D., Jayne, J. T., Herndon, S. C., Trimborn, A. M., Williams, L. R., Wood, E. C., Middlebrook, A. M., Kolb, C. E., Baltensperger, U., and Worsnop, D. R.: Evolution of Organic Aerosols in the Atmosphere, Science, 326, 1525-1529, doi:10.1126/science.1180353, 2009.

Kerminen, V.-M. and Kulmala, M.: Analytical formulae connecting the "real" and the "apparent" nucleation rate and the nuclei number concentration for atmospheric nucleation events, J. Aerosol Sci., 33, 609-622, doi:10.1016/s0021-8502(01)00194-x, 2002.

Kroll, J. H. and Seinfeld, J. H.: Chemistry of secondary organic aerosol: Formation and evolution of low-volatility organics in the atmosphere, Atmos. Environ., 42, 3593-3624, 2008.

Kulmala, M., Laaksonen, A., and Pirjola, L.: Parameterisations for sulphuric acid/water nucleation rates, J. Geophys. Res.-Atmos., 103, 8301-8307, doi:10.1029/97JD03718, 1998.

Kulmala, M., Maso, M. D., Mäkelä, J. M., Pirjola, L., Väkevä, M., Aalto, P., Miikkulainen, P., Hämeri, K., and O'Dowd, C. D.: On the formation, growth and composition of nucleation mode particles, Tellus B, 53, 479-490, doi:10.1034/j.16000889.2001.530411.x, 2001.

Kulmala, M., Lehtinen, K. E. J., and Laaksonen, A.: Cluster activation theory as an explanation of the linear dependence between formation rate of $3 \mathrm{~nm}$ particles and sulphuric acid concentration, Atmos. Chem. Phys., 6, 787-793, doi:10.5194/acp-6-787-2006, 2006.

Kulmala, M., Kontkanen, J., Junninen, H., Lehtipalo, K., Manninen, H. E., Nieminen, T., Petäjä, T., Sipilä, M., Schobesberger, S., Rantala, P., Franchin, A., Jokinen, T., Järvinen, E., Äijälä, M., Kangasluoma, J., Hakala, J., Aalto, P. P., Paasonen, P., Mikkilä, J., Vanhanen, J., Aalto, J., Hakola, H., Makkonen, U., Ruuskanen, T., Mauldin, R. L., Duplissy, J., Vehkamäki, H., Bäck, J., Kortelainen, A., Riipinen, I., Kurtén, T., Johnston, M. V., Smith, J. N., Ehn, M., Mentel, T. F., Lehtinen, K. E. J., Laaksonen, A., Kerminen, V.-M., and Worsnop, D. R.: Direct Observations of Atmospheric Aerosol Nucleation, Science, 339, 943 946, doi:10.1126/science.1227385, 2013.

Lehtinen, K. E. J., Korhonen, H., Dal Maso, M., and Kulmala, M.: On the concept of condensation sink diameter, Boreal Environ. Res., 8, 405-411, 2003.

Makkonen, R., Asmi, A., Korhonen, H., Kokkola, H., Järvenoja, S., Räisänen, P., Lehtinen, K. E. J., Laaksonen, A., Kerminen, V.M., Järvinen, H., Lohmann, U., Bennartz, R., Feichter, J., and Kulmala, M.: Sensitivity of aerosol concentrations and cloud properties to nucleation and secondary organic distribution in ECHAM5-HAM global circulation model, Atmos. Chem. Phys., 9, 1747-1766, doi:10.5194/acp-9-1747-2009, 2009.

Makkonen, R., Asmi, A., Kerminen, V.-M., Boy, M., Arneth, A., Guenther, A., and Kulmala, M.: BVOC-aerosol-climate interactions in the global aerosol-climate model ECHAM5.5-HAM2, Atmos. Chem. Phys., 12, 10077-10096, doi:10.5194/acp-1210077-2012, 2012.

Mann, G. W., Carslaw, K. S., Spracklen, D. V., Ridley, D. A., Manktelow, P. T., Chipperfield, M. P., Pickering, S. J., and 
Johnson, C. E.: Description and evaluation of GLOMAP-mode: a modal global aerosol microphysics model for the UKCA composition-climate model, Geosci. Model Dev., 3, 519-551, doi:10.5194/gmd-3-519-2010, 2010.

Mann, G. W., Carslaw, K. S., Ridley, D. A., Spracklen, D. V., Pringle, K. J., Merikanto, J., Korhonen, H., Schwarz, J. P., Lee, L. A., Manktelow, P. T., Woodhouse, M. T., Schmidt, A., Breider, T. J., Emmerson, K. M., Reddington, C. L., Chipperfield, M. P., and Pickering, S. J.: Intercomparison of modal and sectional aerosol microphysics representations within the same 3-D global chemical transport model, Atmos. Chem. Phys., 12, 4449-4476, doi:10.5194/acp-12-4449-2012, 2012.

Martin, S. T., Andreae, M. O., Artaxo, P., Baumgardner, D., Chen, Q., Goldstein, A. H., Guenther, A., Heald, C. L., Mayol-Bracero, O. L., McMurry, P. H., Pauliquevis, T., Pöschl, U., Prather, K. A., Roberts, G. C., Saleska, S. R., Silva Dias, M. A., Spracklen, D. V., Swietlicki, E., and Trebs, I.: Sources and properties of Amazonian aerosol particles, Rev. Geophys., 48, RG2002, doi:10.1029/2008rg000280, 2010.

Metzger, A., Verheggen, B., Dommen, J., Duplissy, J., Prevot, A. S. H., Weingartner, E., Riipinen, I., Kulmala, M., Spracklen, D. V., Carslaw, K. S., and Baltensperger, U.: Evidence for the role of organics in aerosol particle formation under atmospheric conditions, P. Natl. Acad. Sci., 107, 6646-6651, doi:10.1073/pnas.0911330107, 2010.

Murphy, D. M., Cziczo, D. J., Froyd, K. D., Hudson, P. K., Matthew, B. M., Middlebrook, A. M., Peltier, R. E., Sullivan, A., Thomson, D. S., and Weber, R. J.: Single-particle mass spectrometry of tropospheric aerosol particles, J. Geophys. Res.-Atmos., 111, D23S32, doi:10.1029/2006jd007340, 2006.

Nenes, A. and Seinfeld, J. H.: Parameterization of cloud droplet formation in global climate models, J. Geophys. Res., 108, 4415, doi:10.1029/2002JD002911, 2003.

O'Donnell, D., Tsigaridis, K., and Feichter, J.: Estimating the direct and indirect effects of secondary organic aerosols using ECHAM5-HAM, Atmos. Chem. Phys., 11, 8635-8659, doi:10.5194/acp-11-8635-2011, 2011.

Odum, J. R., Hoffmann, T., Bowman, F., Collins, D., Flagan, R. C., and Seinfeld, J. H.: Gas/Particle Partitioning and Secondary Organic Aerosol Yields, Environ. Sci. Technol., 30, 2580-2585, doi:10.1021/es950943+, 1996.

Pankow, J. F.: An absorption model of the gas/aerosol partitioning involved in the formation of secondary organic aerosol, Atmos. Environ., 28, 189-193, doi:10.1016/1352-2310(94)900949, 1994.

Petters, M. D., Prenni, A. J., Kreidenweis, S. M., DeMott, P. J., Matsunaga, A., Lim, Y. B., and Ziemann, P. J.: Chemical aging and the hydrophobic-to-hydrophilic conversion of carbonaceous aerosol, Geophys. Res. Lett., 33, L24806, doi:10.1029/2006g1027249, 2006.

Pierce, J. R. and Adams, P. J.: Uncertainty in global CCN concentrations from uncertain aerosol nucleation and primary emission rates, Atmos. Chem. Phys., 9, 1339-1356, doi:10.5194/acp-91339-2009, 2009.

Pierce, J. R., Riipinen, I., Kulmala, M., Ehn, M., Petäjä, T., Junninen, H., Worsnop, D. R., and Donahue, N. M.: Quantification of the volatility of secondary organic compounds in ultrafine particles during nucleation events, Atmos. Chem. Phys., 11, 90199036, doi:10.5194/acp-11-9019-2011, 2011.
Pierce, J. R., Leaitch, W. R., Liggio, J., Westervelt, D. M., Wainwright, C. D., Abbatt, J. P. D., Ahlm, L., Al-Basheer, W., Cziczo, D. J., Hayden, K. L., Lee, A. K. Y., Li, S.-M., Russell, L. M., Sjostedt, S. J., Strawbridge, K. B., Travis, M., Vlasenko, A., Wentzell, J. J. B., Wiebe, H. A., Wong, J. P. S., and Macdonald, A. M.: Nucleation and condensational growth to $\mathrm{CCN}$ sizes during a sustained pristine biogenic SOA event in a forested mountain valley, Atmos. Chem. Phys., 12, 3147-3163, doi:10.5194/acp-12-3147-2012, 2012.

Pye, H. O. T. and Seinfeld, J. H.: A global perspective on aerosol from low-volatility organic compounds, Atmos. Chem. Phys., 10, 4377-4401, doi:10.5194/acp-10-4377-2010, 2010.

Rap, A., Scott, C. E., Spracklen, D. V., Bellouin, N., Forster, P. M., Carslaw, K. S., Schmidt, A., and Mann, G.: Natural aerosol direct and indirect radiative effects, Geophys. Res. Lett., 40, 32973301, doi:10.1002/grl.50441, 2013.

Reddington, C. L., Carslaw, K. S., Spracklen, D. V., Frontoso, M. G., Collins, L., Merikanto, J., Minikin, A., Hamburger, T., Coe, H., Kulmala, M., Aalto, P., Flentje, H., Plass-Dülmer, C., Birmili, W., Wiedensohler, A., Wehner, B., Tuch, T., Sonntag, A., O’Dowd, C. D., Jennings, S. G., Dupuy, R., Baltensperger, U., Weingartner, E., Hansson, H.-C., Tunved, P., Laj, P., Sellegri, K., Boulon, J., Putaud, J.-P., Gruening, C., Swietlicki, E., Roldin, P., Henzing, J. S., Moerman, M., Mihalopoulos, N., Kouvarakis, G., Ždímal, V., Zíková, N., Marinoni, A., Bonasoni, P., and Duchi, R.: Primary versus secondary contributions to particle number concentrations in the European boundary layer, Atmos. Chem. Phys., 11, 12007-12036, doi:10.5194/acp-11-12007-2011, 2011. Riccobono, F., Schobesberger, S., Scott, C. E., Dommen, J., Ortega, I. K., Rondo, L., Almeida, J., Amorim, A., Bianchi, F., Breitenlechner, M., David, A., Downard, A., Dunne, E. M., Duplissy, J., Ehrhart, S., Flagan, R. C., Franchin, A., Hansel, A., Junninen, H., Kajos, M. K., Keskinen, H., Kupc, A., Kürten, A., Kvashin, A., Laaksonen, A., Lehtipalo, K., Makhmutov, V., Mathot, S., Nieminen, T., Onnela, A., Petäjä, T., Praplan, A., Santos, F. D., Schallhart, S., Seinfeld, J. H., Sipilä, M., Spracklen, D. V., Stozhkov, Y., Stratmann, F., Tomé, A., Tsagkogeorgas, G., Vaattovaara, P., Viisanen, Y., Vrtala, A., Wagner, P. E., Weingartner, E., Wex, H., Wimmer, D., Carslaw, K. S., Curtius, J., Donahue, N. M., Kirkby, J., Kulmala, M., Worsnop, D. R., and Baltensperger, U.: Oxidation Products of Biogenic Emissions Contribute to Nucleation of Atmospheric Particles, Science, 344, 717-721, doi:10.1126/science.1243527, 2014.

Riipinen, I., Pierce, J. R., Yli-Juuti, T., Nieminen, T., Häkkinen, S., Ehn, M., Junninen, H., Lehtipalo, K., Petäjä, T., Slowik, J., Chang, R., Shantz, N. C., Abbatt, J., Leaitch, W. R., Kerminen, V.-M., Worsnop, D. R., Pandis, S. N., Donahue, N. M., and Kulmala, M.: Organic condensation: a vital link connecting aerosol formation to cloud condensation nuclei (CCN) concentrations, Atmos. Chem. Phys., 11, 3865-3878, doi:10.5194/acp-11-38652011, 2011.

Riipinen, I., Yli-Juuti, T., Pierce, J. R., Petäjä, T., Worsnop, D. R., Kulmala, M., and Donahue, N. M.: The contribution of organics to atmospheric nanoparticle growth, Nat. Geosci, 5, 453-458, doi:10.1038/ngeo1499, 2012.

Rizzo, L. V., Artaxo, P., Müller, T., Wiedensohler, A., Paixão, M., Cirino, G. G., Arana, A., Swietlicki, E., Roldin, P., Fors, E. O., Wiedemann, K. T., Leal, L. S. M., and Kulmala, M.: Long term measurements of aerosol optical properties at a primary 
forest site in Amazonia, Atmos. Chem. Phys., 13, 2391-2413, doi:10.5194/acp-13-2391-2013, 2013.

Robinson, A. L., Donahue, N. M., Shrivastava, M. K., Weitkamp, E. A., Sage, A. M., Grieshop, A. P., Lane, T. E., Pierce, J. R., and Pandis, S. N.: Rethinking Organic Aerosols: Semivolatile Emissions and Photochemical Aging, Science, 315, 1259-1262, doi:10.1126/science.1133061, 2007.

Rossow, W. B. and Schiffer, R. A.: Advances in Understanding Clouds from ISCCP, B. Am. Meteorol. Soc., 80, 2261-2287, 1999.

Schmidt, A., Carslaw, K. S., Mann, G. W., Rap, A., Pringle, K. J., Spracklen, D. V., Wilson, M., and Forster, P. M.: Importance of tropospheric volcanic aerosol for indirect radiative forcing of climate, Atmos. Chem. Phys., 12, 7321-7339, doi:10.5194/acp-127321-2012, 2012.

Scott, C. E., Rap, A., Spracklen, D. V., Forster, P. M., Carslaw, K. S., Mann, G. W., Pringle, K. J., Kivekäs, N., Kulmala, M., Lihavainen, H., and Tunved, P.: The direct and indirect radiative effects of biogenic secondary organic aerosol, Atmos. Chem. Phys., 14, 447-470, doi:10.5194/acp-14-447-2014, 2014.

Sihto, S.-L., Kulmala, M., Kerminen, V.-M., Dal Maso, M., Petäjä, T., Riipinen, I., Korhonen, H., Arnold, F., Janson, R., Boy, M., Laaksonen, A., and Lehtinen, K. E. J.: Atmospheric sulphuric acid and aerosol formation: implications from atmospheric measurements for nucleation and early growth mechanisms, Atmos. Chem. Phys., 6, 4079-4091, doi:10.5194/acp-6-4079-2006, 2006.

Spracklen, D. V., Pringle, K. J., Carslaw, K. S., Chipperfield, M. P., and Mann, G. W.: A global off-line model of sizeresolved aerosol microphysics: I. Model development and prediction of aerosol properties, Atmos. Chem. Phys., 5, 22272252, doi:10.5194/acp-5-2227-2005, 2005.

Spracklen, D. V., Carslaw, K. S., Kulmala, M., Kerminen, V.-M., Mann, G. W., and Sihto, S.-L.: The contribution of boundary layer nucleation events to total particle concentrations on regional and global scales, Atmos. Chem. Phys., 6, 5631-5648, doi:10.5194/acp-6-5631-2006, 2006.

Spracklen, D. V., Carslaw, K. S., Kulmala, M., Kerminen, V.-M., Sihto, S.-L., Riipinen, I., Merikanto, J., Mann, G. W., Chipperfield, M. P., Wiedensohler, A., Birmili, W., and Lihavainen, H.: Contribution of particle formation to global cloud condensation nuclei concentrations, Geophys. Res. Lett., 35, L06808, doi:10.1029/2007g1033038, 2008.

Spracklen, D. V., Carslaw, K. S., Merikanto, J., Mann, G. W., Reddington, C. L., Pickering, S., Ogren, J. A., Andrews, E., Baltensperger, U., Weingartner, E., Boy, M., Kulmala, M., Laakso, L., Lihavainen, H., Kivekäs, N., Komppula, M., Mihalopoulos, N., Kouvarakis, G., Jennings, S. G., O’Dowd, C., Birmili, W., Wiedensohler, A., Weller, R., Gras, J., Laj, P., Sellegri, K., Bonn, B., Krejci, R., Laaksonen, A., Hamed, A., Minikin, A., Harrison, R. M., Talbot, R., and Sun, J.: Explaining global surface aerosol number concentrations in terms of primary emissions and particle formation, Atmos. Chem. Phys., 10, 4775-4793, doi:10.5194/acp-10-4775-2010, 2010.
Spracklen, D. V., Carslaw, K. S., Pöschl, U., Rap, A., and Forster, P. M.: Global cloud condensation nuclei influenced by carbonaceous combustion aerosol, Atmos. Chem. Phys., 11, 9067-9087, doi:10.5194/acp-11-9067-2011, 2011.

Tsigaridis, K., Daskalakis, N., Kanakidou, M., Adams, P. J., Artaxo, P., Bahadur, R., Balkanski, Y., Bauer, S. E., Bellouin, N., Benedetti, A., Bergman, T., Berntsen, T. K., Beukes, J. P., Bian, H., Carslaw, K. S., Chin, M., Curci, G., Diehl, T., Easter, R. C., Ghan, S. J., Gong, S. L., Hodzic, A., Hoyle, C. R., Iversen, T., Jathar, S., Jimenez, J. L., Kaiser, J. W., Kirkevåg, A., Koch, D., Kokkola, H., Lee, Y. H, Lin, G., Liu, X., Luo, G., Ma, X., Mann, G. W., Mihalopoulos, N., Morcrette, J.-J., Müller, J.-F., Myhre, G., Myriokefalitakis, S., Ng, N. L., O’Donnell, D., Penner, J. E., Pozzoli, L., Pringle, K. J., Russell, L. M., Schulz, M., Sciare, J., Seland, Ø., Shindell, D. T., Sillman, S., Skeie, R. B., Spracklen, D., Stavrakou, T., Steenrod, S. D., Takemura, T., Tiitta, P., Tilmes, S., Tost, H., van Noije, T., van Zyl, P. G., von Salzen, K., Yu, F., Wang, Z., Wang, Z., Zaveri, R. A., Zhang, H., Zhang, K., Zhang, Q., and Zhang, X.: The AeroCom evaluation and intercomparison of organic aerosol in global models, Atmos. Chem. Phys., 14, 10845-10895, doi:10.5194/acp-1410845-2014, 2014.

Unger, N.: On the role of plant volatiles in anthropogenic global climate change, Geophys. Res. Lett., 41, 8563-8569, doi:10.1002/2014GL061616, 2014.

Yli-Juuti, T., Nieminen, T., Hirsikko, A., Aalto, P. P., Asmi, E., Hõrrak, U., Manninen, H. E., Patokoski, J., Dal Maso, M., Petäjä, T., Rinne, J., Kulmala, M., and Riipinen, I.: Growth rates of nucleation mode particles in Hyytiälä during 20032009: variation with particle size, season, data analysis method and ambient conditions, Atmos. Chem. Phys., 11, 12865-12886, doi:10.5194/acp-11-12865-2011, 2011.

Yu, F.: A secondary organic aerosol formation model considering successive oxidation aging and kinetic condensation of organic compounds: global scale implications, Atmos. Chem. Phys., 11, 1083-1099, doi:10.5194/acp-11-1083-2011, 2011.

Zhang, Q., Jimenez, J. L., Canagaratna, M. R., Allan, J. D., Coe, H., Ulbrich, I., Alfarra, M. R., Takami, A., Middlebrook, A. M., Sun, Y. L., Dzepina, K., Dunlea, E., Docherty, K., DeCarlo, P. F., Salcedo, D., Onasch, T., Jayne, J. T., Miyoshi, T., Shimono, A., Hatakeyama, S., Takegawa, N., Kondo, Y., Schneider, J., Drewnick, F., Borrmann, S., Weimer, S., Demerjian, K., Williams, P., Bower, K., Bahreini, R., Cottrell, L., Griffin, R. J., Rautiainen, J., Sun, J. Y., Zhang, Y. M., and Worsnop, D. R.: Ubiquity and dominance of oxygenated species in organic aerosols in anthropogenically-influenced Northern Hemisphere midlatitudes, Geophys. Res. Lett., 34, L13801, doi:10.1029/2007GL029979, 2007.

Zhang, X., Pandis, S. N., and Seinfeld, J. H.: Diffusion-Limited Versus Quasi-Equilibrium Aerosol Growth, Aerosol Sci. Tech., 46, 874-885, doi:10.1080/02786826.2012.679344, 2012. 